\title{
EFEKTIVITAS PENGELOLAAN KEGIATAN KELOMPOK KERJA GURU (KKG) DI KECAMATAN REMBANG KABUPATEN PURBALINGGA
}

\author{
Edi Suprijanto; Suharsimi Arikunto \\ SD Negeri I Bantarbarang \\ Email: edisuprijanto@gmail.com
}

\begin{abstract}
Abstrak
Penelitian ini bertujuan untuk mendapatkan gambaran tentang peserta, pembina, materi, kegiatan, dan sarana/prasarana terhadap keefektifan pengelolaan Kegiatan Kelompok Kerja Guru di UPT Dinas Pendidikan Kecamatan Rembang, Purbalingga. Data yang digunakan didapat dari kuisioner yang dibagikan kepada 303 responden. Kuisioner meliputi pertanyaan-pertanyaan mengenai peserta, pembina, materi, kegiatan, dan sarana/prasarana terhadap efektivitas pengelolaan Kelompok Kerja Guru di UPT Dinas Pendidikan Kecamatan Rembang, Purbalingga. Alat analisis yang digunakan adalah uji instrumen (validitas, dan reliabilitas) dan analisis deskriptif kuantitatif. Dari hasil analisis di atas dapat disimpulkan bahwa komponen peserta 96\% sangat efektif, 4,0\% efektif. Komponen pembina $81,8 \%$ sangat efektif, $18,2 \%$ efektif. Komponen materi $80,5 \%$ sangat efektif, 19,5\% efektif. Komponen kegiatan 96,7\% sangat efektif, 3,3\% efektif. Komponen sarana/prasarana $90,8 \%$ sangat efektif, $9,2 \%$ efektif.
\end{abstract}

Kata kunci: efektivitas, kegiatan kelompok kerja (KKG)

\section{THE EFFECTIVENESS OF MANAGING KEGIATAN KELOMPOK KERJA GURU (KKG) IN REMBANG SUB-DISTRICT, PURBALINGGA DISTRICT}

\begin{abstract}
This research aimed to obtain the description concerning participants, superintendent, materials, activities, and facilities/infrastructure on the effectiveness of the management of Kelompok Kerja Guru (KKG)/Teacher Working Group activities in UPT Dinas Pendidikan (Sub-district Education Office) of Rembang Sub-district, Purbalingga. The data were collected by using questionnaires distributed to 303 respondents. The questionnaires involved questions participants, coaches, materials, activities, and facilities /infrastructure on the effectiveness of the management of KKG activities in UPT Dinas Pendidikan Rembang Sub-district, Purbalingga. The analysis instruments adopted comprised instrument test (validitity, and reliability) analisis deskriptif kuantitatif. Based on the analysis, it could be concluded that the component of participants is $96 \%$ very effective, $4 \%$ effective. Component of superintendent is $81.8 \%$ very effective, and $18.2 \%$ effective. The component of materials is 80,5 very effective, $19.5 \%$ effective. The component of activities is $96.7 \%$ very effective, $3.3 \%$ effective. The component of facilities/infrastructure is $90.8 \%$, and $9.2 \%$ effective.
\end{abstract}

Keywords: effectiveness, kegiatan kelompok kerja (KKG)

\section{PENDAHULUAN}

Posisi guru dalam dunia pendidikan adalah sebagai garda terdepan dan sentral terlaksananya proses pembelajaran. Berkaitan dengan mutu pendidikan berarti juga akan membicarakan guru, baik itu yang berkaitan dengan kinerja, totalitas, dedikasi, maupun loyalitas sebagai seorang pendidik dan pencetak bekalbekal sumber daya manusia (SDM), termasuk konsekuensi guru profesional yakni harus memiliki sertifikat pendidik. 
Sallis menyebutkan bahwa makna mutu atau kualitas adalah "an absolute and a relative concept." Kualitas menurut konsep absolute adalah "the highest possible standard which can not be surpassed." Dalam konsep relatif, produk atau jasa dianggap berkualitas jika barang atau jasa memenuhi standar yang ditetapkan. Menurut konsep ini mutu memiliki dua aspek, yaitu (a) measuring up to specification artinya berdasarkan spesifikasi yang telah ditetapkan oleh produsen, dan (b) meeting customer requirements artinya memenuhi keperluan pelanggan (Sallis, 2003:2-24).

Rinehart (1999:26) menyatakan mutu merupakan "the aggregate characteristics of a product or service that satisfy the needs of the customer, where the customer may be either the immediate recipient or the ultimate user of the product or service, or both". Mutu merupakan kumpulan karakteristik produk atau layanan yang memuaskan kebutuhan pelanggan. Definisi konvensional menggambarkan mutu sebagai karakteristik langsung dari suatu produk seperti: performansi (performance), keandalan (reliability), mudah dalam penggunaan (ease of use), estetika (esthetics), dan sebagainya. Definisi strategik menyatakan bahwa mutu adalah segala sesuatu yang mampu memenuhi keinginan atau kebutuhan pelanggan (meeting the needs of customer).

Sebenarnya, beban tanggung jawab membawa peserta didik ke gerbang keberhasilan bukan semata di pundak guru. Tetapi juga orang tua dan masyarakat ikut bertanggung jawab menentukan keberhasilan pendidikan. Definisi guru sebagai pendidik profesional dengan tugas mendidik, mengajar, membimbing, mengarahkan, melatih, menilai, dan mengevaluasi peserta didik pada pendidikan anak usia dini jalur pendidikan formal, pendidikan dasar, dan pendidikan menengah, suatu tugas mulia yang mesti dihargai.

Dalam UU 14 tahun 2005 tentang Guru dan Dosen serta PP No.19/2005 tentang Standarisasi Pendidikan menuntut seorang guru harus memiliki syarat-syarat sehingga layak dipandang sebagai guru profesional. Salah satu syarat tersebut adalah guru harus memiliki sertifikat atau semacam lisensi dari pemerintah pusat atau dari perguruan tinggi tertentu yang terakreditasi. Berangkat dari sini akan dapat diklarifikasi, mana saja guru yang pantas menyandang status guru profesional dan mana yang belum pantas, sehingga ke depannya guru tersebut harus kembali dibekali sehingga kelak layak memperoleh sertifikat dan status guru profesional. Upaya untuk meningkatkan mutu pendidikan minimal memilah dan memilih guru melalui uji kompetensi menuju terpilihnya guru profesional, merupakan indikator penting dalam meningkatkan pendidikan bermutu yang akan menghasilkan sumber daya yang bermutu pula, pada akhirnya akan mengangkat kualitas bangsa. Indikator suatu bangsa salah satunya ditentukan oleh kualitas sumber daya manusianya, sedangkan indikator sumber daya manusia ditentukan oleh mutu pendidikan masyarakatnya. Tinggi rendahnya mutu pendidikan tak dapat dielakkan salah satu penentunya adalah guru.

Berdasarkan data dalam Education For All (EFA) Global Monitoring Report 2011: Di Balik Krisis: Konflik Militer dan Pendidikan yang dikeluarkan Organisasi Pendidikan, Ilmu Pengetahuan, dan Kebudayaan Perserikatan Bangsa-Bangsa (UNESCO) yang diluncurkan di New York, Amerika Serikat, indeks pembangunan pendidikan (education development index/EDI) menurut data tahun 2008 adalah 0,934. Nilai ini menempatkan Indonesia di posisi ke-69 dari 127 negara di dunia. Gambaran ini mencerminkan bagaimana mutu pendidikan memengaruhi mutu sumber daya manusia. Guru yang profesional dengan kinerja maksimal, totalitas dedikasi, dan loyalitas pengabdian dijadikan sebagai tumpuan untuk mengubah wajah pendidikan menjadi cerah sehingga terbentuk output 
pendidikan yang menjadi harapan bangsa sebagai sumber daya berkualitas. Jadi sebagai dasar pendidikan bangsa guru merupakan sosok kunci penentu keberhasilan pendidikan bangsa di masa datang. Sehubungan dengan itu, Departemen Pendidikan Nasional (Depdiknas) mengadakan tiga kebijakan pokok, yakni melalui (1) perluasan sumber dan pemerataan akses pendidikan, (2) peningkatan mutu, relevansi, dan daya saing, dan (3) penguatan tata kelola, akuntabilitas, dan pencitraan publik. Pada tataran operasional, peningkatan mutu pendidikan nasional diarahkan untuk penjaminan mutu pendidikan masyarakat. Karenanya, pendidikan pada satuan pendidikan "harus" dilaksanakan sesuai standar nasonal pendidikan dan sesuai dengan harapan dan kebutuhan masyarakat yang terus berkembang secara dinamis dengan memberdayakan pendidik dan tenaga kependidikan yang terwadahi dalam berbagai forum secara optimal.

Proses dari timbulnya kesadaran untuk meningkatkan kemampuan profesional di kalangan guru, timbulnya kesempatan dan usaha, meningkatnya kualitas profesional sampai tercapainya jenjang kepangkatan dan jabatan yang tinggi memerlukan iklim yang memungkinkan berlangsungnya proses di atas. Iklim yang kondusif hanya akan muncul apabila di kalangan guru timbul hubungan kesejawatan yang baik, harmonis, dan obyektif. Hubungan tersebut bisa dimunculkan antara lain lewat kegiatan profesional kesejawatan. Dengan demikian, untuk pembinaan dan peningkatan profesional guru perlu dikembangkan kegiatan professional kesejawatan yang baik, harmonis, dan obyektif. Secara sistematis pengembangan kesejawatan ini memerlukan: wadah/kelembagaan, (2) bentuk kegiatan, (3) mekanisme.

Konsep pengembangan profesionalisme menurut para akhli dapat didefinisikan bermacam-macam. Salah satu pendapat dikemukakan oleh Alba \& Sandberg (2006:384) sebagai berikut: "...the concept of professional development is not clearly delimited. A profession traditionally is defined as being based on systematic,scientific knowledge. Prehminary development of professional skill has occurred largely through designated higher education program, with subsequent development taking various forms."

Konsep pengembangan professional tidaklah dengan jelas dibatasi suatu profesi digambarkan sebagai dasar pengetahuan sistematis dan pengetahuan ilmiah. Pengembangan ketrampilan profesional telah dirancang luas melalui program pendidikan lebih tinggi dengan berbagai bentuk pengembangan.

Guru adalah tenaga professional yang melaksanakan profesi pembelajaran. Jika guru dapat menciptakan dan memelihara hubungan antar sesama, baik kepala sekolah, guru, siswa, dan staf, berdasarkan lingkungan kerja maupun dalam hubungan keseluruhan maka maka tercipta lingkungan kerja yang nyaman. Sebagai jabatan professional guru harus meningkatkan pengetahuan, sikap, dan keterampilan secara terus menerus, di samping guru harus menjawab tantangan perkembangan masyarakat, jabatan guru harus dikembangkan.

Profesionalisme menurut Pratte \& Rury (Shon, 2006:4) adalah "an ideal to which individuals and accupational groups aspire, in onder to distinguish themselves from other workers". Artinya cita-cita yang individu dan kelompok kerja inginkan, untuk membedakan diri dari pekerja lain.

$$
\text { Menurut Syah }
$$

"kompetensi" adalah kemampuan, kecakapan, keadaan berwenang, atau memenuhi syarat menurut ketentuan hukum. Kompetensi guru merupakan kemampuan seorang guru dalam melaksanakan kewajiban-kewajibannya secara bertanggung jawab dan layak. Jadi kompetensi profesional guru dapat diartikan sebagai kemampuan dan kewenangan guru dalam menjalankan profesi keguruannya. Guru yang 
kompeten dan profesional adalah guru yang piawai dalam melaksanakan profesinya.

Kata "profesional" erat kaitannya dengan kata "profesi". Profesi adalah pekerjaan yang untuk melaksanakannya memerlukan sejumlah persyaratan tertentu (Wirawan, 2002:9). Definisi ini menyatakan bahwa suatu profesi menyajikan jasa yang berdasarkan ilmu pengetahuan yang hanya difahami oleh orang-orang tertentu yang secara sistematik diformulasikan dan diterapkan untuk memenuhi kebutuhan klien, dalam hal ini masyarakat. Salah satu contoh profesi yaitu guru.

Usaha meningkatkan kualitas guru di tingkat yang paling nyata berada di sekolah. Setiap sekolah seharusnya mengadakan in service training, in service training tidak hanya pada wilayah prinsip pendidikan (pengajaran), melainkan juga pada wilayah teknis pragmatis dan aktivitas pengajaran sehari-hari. Itu artinya, dalam hal ini adalah guru dituntut harus selalu membaca, dan belajar, serta memburu ilmu pendidikan yang setiap saat berkembang untuk kemudian diterapkan dalam pelaksanaan sehari-hari.

Profesi pada hakekatnya adalah sikap yang bijaksana (informed responsifveness) yaitu pelayanan dan pengabdian yang dilandasi oleh keahlian, kemampuan, teknik dan prosedur yang mantap diiringi sikap kepribadian tertentu. Profesi adalah sebagai suatu spesialisasi dari jabatan intelektual yang diperoleh melalui studi dan training, bertujuan mensuplai keterampilan melalui pelayanan dan bimbingan pada orang lain untuk mendapatkan bayaran (fee) atau gaji. Jika dikaitkan dengan kajian sosiologik, maka dapat dipersepsikan bahwa profesi itu sesungguhnya suatu jenis model atau tipe pekerjaan ideal, karena dalam realitasnya bukanlah hal yang mudah untuk diwujudkan.

Sejalan dengan itu Komarudin (2000:205) mengemukakan bahwa profesional berasal dari bahasa latin "profesia", pekerjaan, keahlian, jabatan, guru besar. Seseorang yang melibatkan diri dalam salah satu keahlian yang harus dipelajari dengan khusus; lawannya adalah amatir. Pengembangan profesional guru dimaksudkan untuk memenuhi tiga kebutuhan yaitu: 1) kebutuhan sosial untuk meningkatkan kemampuan sistem pendidikan yang efisien dan manusiawi, serta melakukan adaptasi untuk penyusunan kebutuhan-kebutuhan sosial, 2) kebutuhan untuk menemukan cara untuk membantu staf pendidikan dalam rangka mengembangkan pribadinya secara luas. Dengan demikian, guru dapat mengembangkan potensi sosial dan potensi akademik generasi muda dalam interaksinya dengan alam lingkungan, 3) kebutuhan untuk mengembangkan dan mendorong keinginan guru untuk menikmati dan mendorong kehidupan pribadinya, seperti halnya dia membantu siswanya dalam mengembangkan keinginan dan keyakinan untuk memenuhi keinginan pribadi yang sesuai dengan potensinya (Danim, 2002:51).

Berdasarkan definisi tersebut di atas, maka dapat disimpulkan bahwa profesionalisme guru adalah seperangkat kemampuan guru dalam menjalankan tugas profesionalnya dengan berbekal keahlian yang tinggi, rasa keterpanggilan jiwa, dan komitmen untuk melakukan pengabdian memberikan layanan kepada orang lain. Profesionalisme guru dapat dilihat dari kemampuan guru dalam melaksanakan semua kompetensi profesional yang dipersyaratkan untuk melakukan tugas mendidik, mengajar, dan membimbing.

Salah satu upaya yang dilakukan pemerintah untuk mengembangkan profesional guru Sekolah Dasar (SD), adalah dengan Sistem Pembinaan Profesional (SPP) melalui wadah Kelompok Kerja Guru (KKG), Kelompok Kerja Kepala Sekolah (KKKS), dan Kelompok Kerja Pengawas Sekolah (KKPS). Sistem Pembinaan Profesional yang tergabung dalam gugus sekolah telah dibakukan dalam SK Dirjen Dikdasmen Depdikbud.No.070/C/Kep/I/93 tanggal 7 
April 1993. Pengembangan profesional dimaksudkan untuk mengembangkan suatu jaringan dan sistem pembinaan kreatif dengan melibatkan secara aktif seluruh pembina guru dalam suatu kegiatan profesional terpadu (Depdikbud, 2009:1).

Pemberdayaan KKG dan MGMP, diharapkan dapat mendukung secara optimal peningkatan kemampuan professional guru dalam pembelajaran di sekolah terkait. Namun, laporan evaluasi pelaksanaan kegiatan KKG yang belum meningkatkan kinerja yang berarti. Di beberapa daerah peningkatan KKG cukup menggembirakan, namun di sebagian besar lainnya masih memprihatinkan. Masalah utama yang dihadapi antara lain:(1) belum adanya rambu-rambu petunjuk yang digunakan sebagai acuan bagi guru dan pengurus KKG dalam melakukan aktifitas kelompok kerja, (2) belum intensifnya program pendampingan yang dilaksanakan instruktur terhadap guru sebagai tindak lanjut pelaksanaan (Depdikbud, 2009:2).

Dalam konteks itu, guru perlu didorong secara terus menerus untuk senantiasa meningkatkan profesionalismenya. Oleh karena itu, pemberdayaan KKG dan MGMP dipandang sangat strategis untuk meningkatkan mutu guru.

Upaya mengevaluasi jalannya suatu organisasi dapat dilakukan melalui konsep efektifitas. Konsep ini adalah salah satu faktor untuk menentukan apakah perlu dilakukan perubahan secara signifikan terhadap bentuk dan managemen organisasi atau tidak. Hal ini efektifitas merupakan tujuan organisasi melalui pemanfaatan sumber daya yang dimiliki secara efisien ditinjau dari masukan (input), process, output, dan outcome. Dalam hal ini yang dimaksud sumber daya meliputi kesediaan personil (peserta), pembina, materi, kegiatan, dan sarana /prasarana yang tersedia.

Menurut Nawawi (1981:34) pembinaan dimaksudkan untuk menumbuhkan sikap yang positif pada guru agar mampu menilai diri sendiri ke arah terbentuknya keterampilan dan ilmu pengetahuan yang selalu berkembang. Fokus pembinaan adalah memberi kesempatan pada guru untuk mengembangkan kemampuan dalam mengelola kegiatan belajar mengajar, kegiatan pembinaan lebih bersifat akademik yakni dititik beratkan pada peningkatan proses belajar megajar

Suatu kegiatan dikatakan efektif apabila dikerjakan sesuai dengan prosedur, sedangkan dikatakan efisien apabila kegiatan tersebut dilaksanakan dengan benar dan memberikan hasil yang bermanfaat.

Program kegiatan akan dapat diketahui maju mundurnya suatu organisasi perlu adanya evaluasi program. Hal tersebut digunakan untuk mengumpulkan informasi tentang bekerjanya sesuatu yang selanjutnya informasi tersebut digunakan untuk menentukan alternatif yang tepat dalam mengambil sebuah keputusan.

Arikunto (2004:1) menjelaskan bahwa evaluasi adalah suatu kegiatan untuk mengumpulkan informasi tentang bekerjanya sesuatu, yang selanjutnya informasi tersebut digunakan untuk menentukan alternatif yang tepat dalam mengambil sebuah keputusan. Menurut Tyler (Fernandes, 1984:1) "evaluation as the process of determining to what extent the educationnal objectives are being realized". Sedangkan menurut Stufflebeam (Worthem \& Sanders, 1987:129), evaluasi adalah "Evaluation is the process of delineating, obtaining and providing useful information for judging decision alternative, process a particular, continuing and cyclical activity. Delineating focusing information requirements to be served evaluation through such steps as specifying, defining and explicatting, abtaining, making,available through such processes as collecting, organizing, and analyzing, and through such formal means as statistic and meansurement. Providing, fitting together into system or sub system 
that best served the needs or purposes of the evaluation".

Berdasarkan uraian tersebut evaluasi adalah proses yang menggambarkan, menghasilkan, dan menyajikan informasi yang berguna untuk pengambilan keputusan. Dengan demikian evaluasi merupakan kegiatan yang sistematis untuk pengambilan keputusan dalam menentukan kebijakan suatu program yang dievaluasi.

Worthen \& Sanders (1987:19) mendefinisikan "Evaluation is the determination of the worth of a thing. It includes obtaining informationfor use in judging the worth of program, product, procedure, or objective or the potential unility of alternative approach designed to attain specified objectives." Sementara Mahrens \& Lehmann (1973:6) merumuskan evaluasi "as a process that allows one to make a judgment about the desirability or value of a measure". Bahwa evaluasi merupakan suatu proses membuat keputusan berdasarkan nilai atau ukuran yang telah ditentukan. Pendapat lain yang dikemukakan oleh Kaufman \& Thomas (1980:4) "evaluation is proscess used to assess the quality of what is going on" yang artinya evaluasi adalah suatu proses yang digunakan untuk menilai mutu dari apa yang sedang berlangsung.

Dengan demikian, dapat disimpulkan bahwa pada umumnya berkaitan dengan upaya pengumpulan, pengelolaan, dan penyajian data atau informasi sebagai masukan untuk pengambilan keputusan. Hasil evaluasi dapat dipergunakan untuk menentukan nilai atau tingkat keberhasilan program dilihat dari segi kualitas kinerja pelaksana untuk kepentingan apakah program dilanjutkan, dimodifikasi, atau dihentikan.

Para ahli evaluasi telah berhasil merancang model evaluasi yang dapat digunakan evaluator. Kaufman dan Thomas (1980:109-110) membedakan model evaluasi ke dalam delapan model yaitu: a) Formative summative evaluation model, b) Chip evaluation model, c) Center for the Study of Evaluation, d)
Countenance Evaluation Model, e) Goal Attainment Evaluation, f) Discrepancymodel, g) Goal Free Evaluation, h) Responsive Evaluation Model.

Menurut Weiss (1972:4) kegunaan penelitian evaluasi adalah sebagai berikut: (1) menunjukkan pada penggunaan metode penelitian, (2) menekankan pada hasil suatu program atau dampak program, (3) penggunaan kriteria untuk menilai dan (4) konstribusi terhadap pengambilan keputusan dan peningkatan perencanaan program di masa mendatang menunjuk pada tujuan social. Pada dasarnya tujuan evaluasi adalah untuk memperoleh data atau informasi akurat dan objektif tentang pelaksanaan suatu program. Informasi tersebut dapat mengenai dampak atau hasil yang dicapai, proses, efisiensi atau pemanfaatan pendayagunaan sumber daya. Untuk pemanfaatan hasil dapat tertujukan pada program itu sendiri atau untuk mempertanggungjawabkan administrasi kepada penyandang dana dalam rangka publikasi atas keberhasilan program guna memperoleh simpati dan pengakuan masyarakat luas.

Widoyoko (2009:294) mengemukakan bahwa kriteria adalah ukuran yang menjadi dasar penilaian atau penetapan sesuatu, sedangkan Sugiyono (2009:246) menjelaskan bahwa kriteria berhubungan dengan tekhnik analisis data untuk menjawab rumusan masalah atau pertanyaan yang bersifat deskriptif yaitu: untuk dapat menjawab keempat rumusan masalah deskriptif tersebut, maka pertama-tama ditentukan terlebih dahulu dalam skor idea/kriterium. Skor ideal yaitu skor yang ditetapkan dengan asumsi bahwa setiap responden pada setiap pertanyaan memberi jawaban dengan skor tertinggi. Selanjutnya untuk menjawab kelima rumusan masalah tersebut, dapat dilakukan dengan cara membandingkan jumlah skor hasil penelitian dengan skor ideal.

Sutrisno Hadi (2004:120-121) mengemukakan kriteria dalam kaitannya dengan prinsip validasi, yaitu "Prinsip dari 
validasi adalah membandingkan hasilhasil dari pengukuran faktor dengan suatu kriteria, suatu ukuran yang telah dipandang valid untuk menunjukkan faktor yang dimaksudkan". Ada dua jenis kriteria yang digunakan untuk menguji kejituan alat pengukur, yaitu, (1) kriteria luar (external criteria), dan (2) kriteria dalam (internal criteria). Kriteria luar adalah kriteria yang diambil dari luar alat pengukur. Contohnya tes ketelitian kerja diuji validitasnya dengan prestasi kerja yang sesungguhnya seperti ditunjukkan catatan hasil kerja atau penilaian pimpinan unit kerja. Kriteria dalam adalah kriteria yang diambil dari keseluruhan hasil pengukuran. Istilah "kriteria" dalam penelitian sering juga dikenal dengan kata tolok ukur atau standar. Dari nama-nama yang digunakan tersebut dapat segera dipahami bahwa kriteria, tolok ukur, dan standar, adalah sesuatu yang digunakan sebagai patokan atau batas minimal untuk suatu yang diukur.

Unit Pelayanan Teknis Dinas Pendidikan Kecamatan Rembang, telah melakukan berbagai upaya untuk meningkatkan profesionalisme guru sekolah dasar. Upaya yang telah dilakukan antara lain memberdayakan guru untuk mengikuti pelatihan, penataran di tingkat kabupaten maupun provinsi. Sudah banyak guru yang telah mengikuti pelatihan namun tidak ditindaklanjuti untuk ditularkan pada forum KKG. Secara geografis, Kecamatan Rembang merupakan desa yang sangat jauh dari kota kabupaten. Tempat sekolah dasar pun bervariasi. Tidak sedikit jalan yang harus dilalui belum diaspal. Hal ini juga sebagai salah satu alasan bahwa guru malas untuk mengikuti KKG di tingkat gugus. Di sisi lain kegiatan $\mathrm{KKG}$ yang sudah berjalan pun kurang adanya perhatian dari pembina di tingkat Kecamatan.

Berdasarkan latar belakang di atas, maka penulis tertarik untuk meneliti Keefektifan Pengelolaan Kegiatan Kelompok Kerja Guru (KKG) di UPT Dinas Pendidikan Kecamatan Rembang, Kabupaten Purbalingga

\section{METODE}

Jenis Penelitian

Penelitian ini menggunakan pendekatan kuntitatif, dan jenis penelitian evaluasi yang bermaksud mendeskripsikan pelaksanaan kegiatan Kelompok Kerja Guru di UPT Dinas Pendidikan Kecamatan Rembang. Keefektifan pelaksanaan kegiatan KKG dipengaruhi dari berbagai komponen di antaranya peserta, pembina, materi, kegiatan, dan sarana/prasarana

Waktu Pelaksanaan Penelitian

Penelitian ini dilaksanakan mulai bulan Maret 2013 sampai bulan Mei 2013. Mengambil tempat di gugus KKG pada Kecamatan Rembang, Kabupaten Purbalingga. Gugus pada wilayah Kecamatan Rembang terdiri dari empat kelompokdi Gugus Jenderal Soedirman, Gugus Rubiyah Sekar, Gugus Krida Manggala dan Gugus Jambu Karang

Populasi dan Sampel

Populasi dalam penelitian ini adalah semua guru SD di wilayah Kecamatan Rembang, Kabupaten Purbalingga yang aktif dalam kegiatan KKG yang berjumlah 303 guru. Hal tersebut dimaksudkan untuk menjaring informasi yang lengkap dengan kebutuhan penelitian ini

Penelitian ini merupakan penelitian populasi dengan jumlah 303 guru SD yang berkedudukan di Gugus Jenderal Soedirman, Gugus Rubiyah Sekar, Gugus Krida Manggala dan Gugus Jambu Karang.

Prosedur

Dalam penelitian ini menggunakan kuesioner tertutup dengan bentuk Rating Scale (skala bertingkat). Untuk menentukan skor atau nilai jawaban angket, digunakan Skala Likert. Dengan Skala Likert diharapkan peneliti dapat mengetahui bagaimana tingkatantingkatan pendapat responden serta memberi kemungkinan untuk menilai setiap item yang diteliti. Skala likert 
dengan lima kategori, yaitu: Sangat sesuai diberi bobot 4, Sesuai diberi bobot 3, Tidak sesuai diberi bobot 2, Sangat tidak sesuai diberi bobot 1 .

Tabel 1 Skor untuk Pertanyaan/Pernyataan dalam Angket Tersusun

\begin{tabular}{clcl}
\hline Skor & $\begin{array}{c}\text { Pernyataan } \\
\text { Positif }\end{array}$ & skor & $\begin{array}{c}\text { Pernyataan } \\
\text { Negatif }\end{array}$ \\
\hline 4 & Sangat sesuai & 1 & Sangat sesuai \\
3 & Sesuai & 2 & Sesuai \\
2 & Tidak seesuai & 3 & Tidak sesuai \\
1 & Sangat tidak & 4 & Sangat tidak \\
& seseuai & & \\
\hline
\end{tabular}

Teknik analisis data yang digunakan adalah analisis deskriptif kuantitatif, yaitu mendeskripsikan dan memaknai data kemudian dibandingkn dengan acuan kriteria yang telah ditentukan berdasarkan rata-rata ideal dan simpangan baku ideal yang dapat dicapai oleh instrumen kemudian dikelompokkan ke dalam lima kategori (Chabib Thoha, 2001: 100)

Yaitu:

Skor $\geq M+(1,5 \mathrm{SD}):$ Sangat efektif

$\mathrm{M}+(0,5 \mathrm{SD}) \leq \mathrm{Skor}<\mathrm{M}+(1,5 \mathrm{SD}) \quad$ :

Efektif

$\mathrm{M}-(0,5 \mathrm{SD}) \leq$ Skor $<\mathrm{M}+(0,5 \mathrm{SD}) \quad$ :

Cukup efektif

$\mathrm{M}-(1,5 \mathrm{SD}) \leq$ Skor $<\mathrm{M}-(0,5 \mathrm{SD}) \quad$ :

Kurang efektif

Skor $<M-(1,5 \mathrm{SD}) \quad$ : Tidak efektuf

\section{HASIL DAN PEMBAHASAN}

Setelah proses pengambilan sampel dan dilanjutkan dengan pengolahan data penelitian maka didapatkan hasil keefektifan pengelolaan kegiatan kelompok kerja guru di UPT Dinas Pendidikan Kecamatan Rembang, pada masing-masing gugus sebagai berikut:

a) Komponen Peserta

Dari hasil analisis statistik komponen peserta pada masing masing gugus yaitu: pada gugus Jenderal Sodirman $95,0 \%$ kategori sangat efektif, dan 5,0\% efektif, gugus Rubiah sekar 100,0\% kategori sangat efektif, dan gugus Krida Manggala 94,9\% sangat efektif, dan 5,1\% efektif, serta gugus Syeh Jambukarang 94.7\% sangat efektif, dan 5,7\% efektif. Dari kategori masing-masing gugus di wilayah UPT Dinas Pendidikan Kecamatan Rembang dapat disimpulkan bahwa komponen anggota dalam pengelolaan kegiatan Kelompok Kerja Guru sangat efektif $96,0 \%$, dan efektif 4,0\%. Hasil tersebut dapat dilihat pada tabel 2 berikut:

Tabel 2

Kategori komponen Peserta

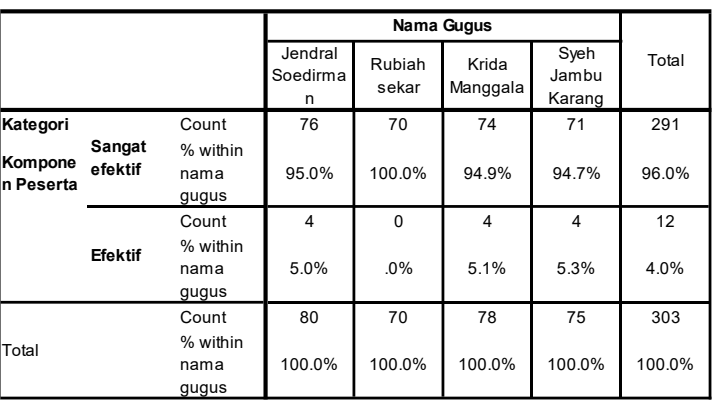

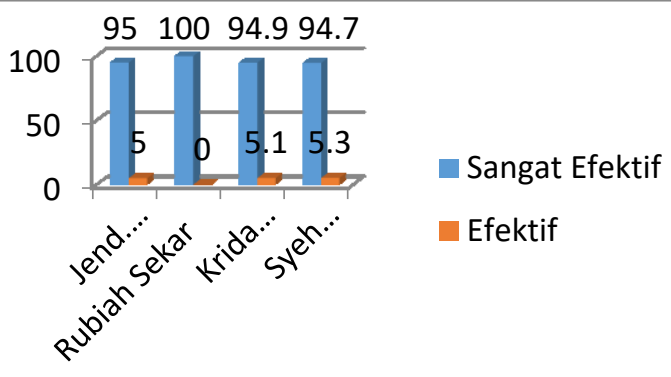

Gambar 1

Efektifitas Komponen Peserta

b) Komponen Pembina

Dari hasil analisis statistik komponen pembina pada masing masing gugus yaitu: pada gugus Jenderal Sodirman 82,5,0\% kategori sangat efektif, dan $17,5 \%$ efektif, gugus Rubiah sekar $81,4 \%$ kategori sangat efektif, dan 18,6 efektif, gugus Krida Manggala $80,8 \%$ sangat efektif, dan $19,2 \%$ efektif, serta gugus Syeh Jambukarang $82.7 \%$ sangat efektif, dan $17,3 \%$ efektif. Dari kategori asingmasing gugus di wilayah UPT Dinas Pendidikan Kecamatan Rembang dapat 
disimpulkan bahwa komponen anggota dalam pengelolaan kegiatan Kelompok Kerja Guru sangat efektif $81,8 \%$, $18,2 \%$ efektif. Hasil tersebut dapat dilihat pada tabel 3 berikut:
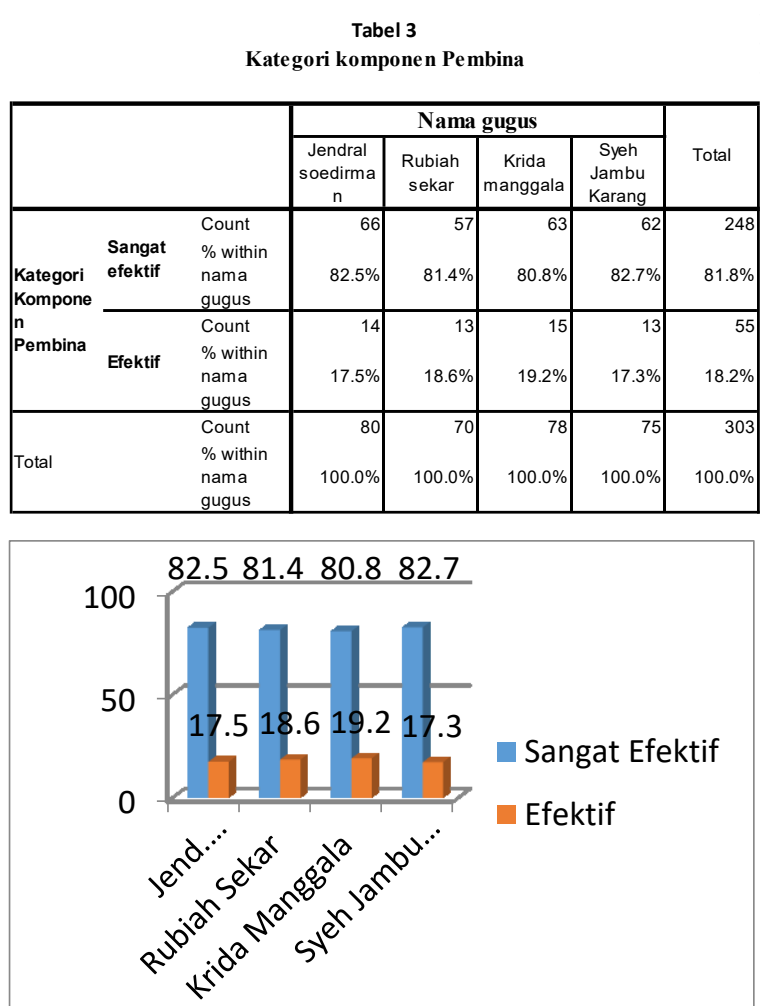

Gambar 2

Efektifitas Komponen Pembina

c) Komponen Materi

Dari hasil analisis statistik komponen materi pada masing masing gugus yaitu: pada gugus Jenderal Sodirman $81,3 \%$ kategori sangat efektif, dan $18,7 \%$ efektif, gugus Rubiah sekar $80,0 \%$ kategori sangat efektif, dan 20,0 efektif, gugus Krida Manggala 79,5\% sangat efektif, dan $20,5 \%$ efektif, serta gugus Syeh Jambukarang $81.3 \%$ sangat efektif, dan $18,7 \%$ efektif. Dari kategori asingmasing gugus di wilayah UPT Dinas Pendidikan Kecamatan Rembang dapat disimpulkan bahwa komponen materi dalam pengelolaan kegiatan Kelompok Kerja Guru sangat efektif 80,5\%, $19,5 \%$ efektif. Hasil tersebut dapat dilihat pada tabel 4 berikut:

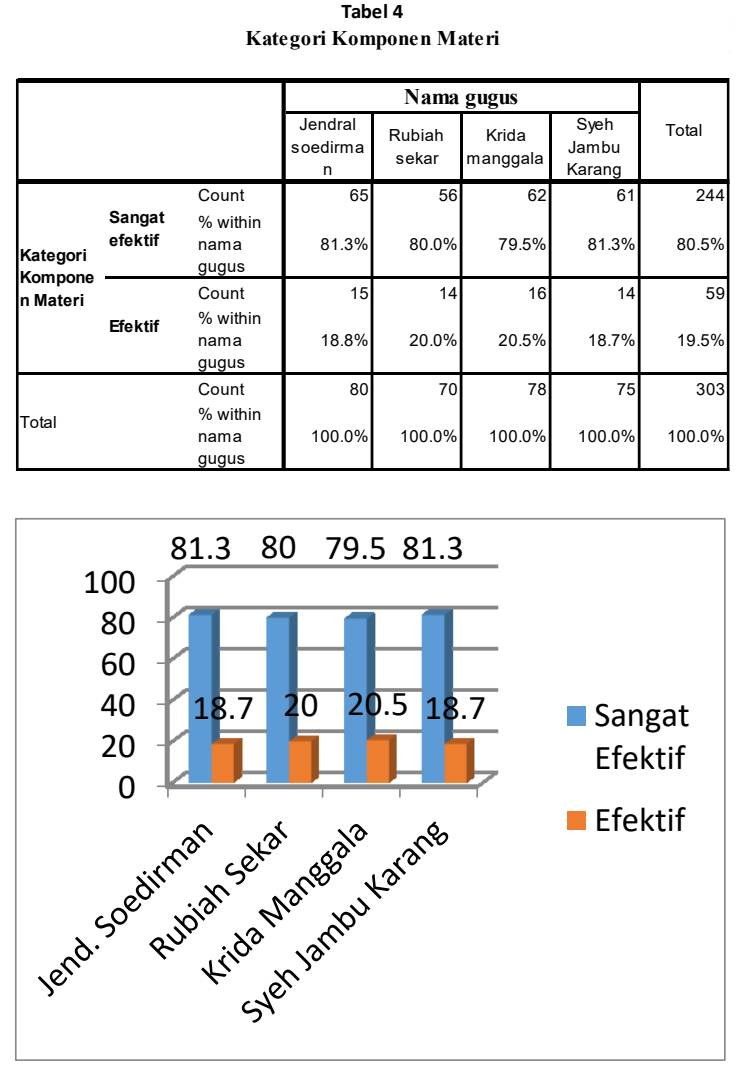

Gambar 3

Efektifitas Komponen Materi

d) Komponen Kegiatan

Dari hasil analisis statistik komponen kegiatan pada masing masing gugus yaitu: pada gugus Jenderal Sodirman 96,3\% kategori sangat efektif, dan 3,7\% efektif, gugus Rubiah sekar 98,6\% kategori sangat efektif, dan 1,4\% efektif, gugus Krida Manggala 96.2\% sangat efektif, dan $3,8 \%$ efektif, serta gugus Syeh Jambukarang 96,0\% sangat efektif, dan $4,0 \%$ efektif. Dari kategori asingmasing gugus di wilayah UPT Dinas Pendidikan Kecamatan Rembang dapat disimpulkan bahwa komponen anggota dalam pengelolaan kegiatan Kelompok Kerja Guru sangat efektif 96,7\%, dan $3,3 \%$ efektif. Hasil tersebut dapat dilihat pada tabel 5 berikut: 
Tabel 5

Kategori Komponen Kegiatan

\begin{tabular}{|c|c|c|c|c|c|c|c|}
\hline & \multicolumn{4}{|c|}{ Nama gugus } & \multirow[b]{2}{*}{ Total } \\
\hline & & & $\begin{array}{c}\text { Jendral } \\
\text { soedirma } \\
n\end{array}$ & $\begin{array}{l}\text { Rubiah } \\
\text { sekar }\end{array}$ & $\begin{array}{c}\text { Krida } \\
\text { manggala }\end{array}$ & $\begin{array}{l}\text { Syeh } \\
\text { Jambu } \\
\text { Karang }\end{array}$ & \\
\hline \multirow{3}{*}{$\begin{array}{l}\text { Kategori } \\
\text { Kompone } \\
\text { n } \\
\text { Kegiatan }\end{array}$} & & Count & 77 & 69 & 75 & 72 & 2 \\
\hline & $\begin{array}{l}\text { Sangat } \\
\text { efektif }\end{array}$ & $\begin{array}{l}\% \text { within } \\
\text { nama } \\
\text { gugus }\end{array}$ & $96.3 \%$ & $98.6 \%$ & $96.2 \%$ & $96.0 \%$ & $96.7 \%$ \\
\hline & Efektif & $\begin{array}{l}\text { Count } \\
\% \text { within } \\
\text { nama } \\
\text { gugus }\end{array}$ & $3.8 \%$ & $1.4 \%$ & $3.8 \%$ & $4.0 \%$ & $3.3 \%$ \\
\hline Total & & $\begin{array}{l}\text { Count } \\
\% \text { within } \\
\text { nama } \\
\text { gugus }\end{array}$ & $100.0 \%$ & $100.0 \%$ & $100.0 \%$ & $100.0 \%$ & $100.0 \%$ \\
\hline
\end{tabular}

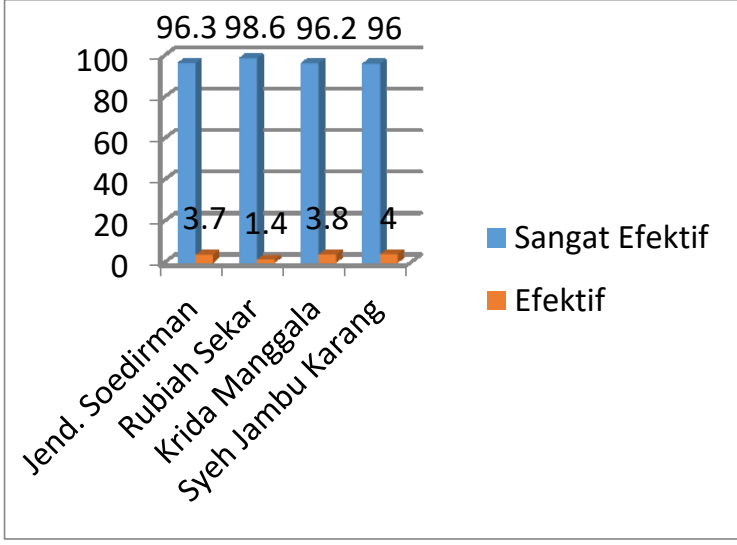

Gambar 4

Efektifitas Komponen Kegiatan

e) Komponen Sarana/prasarana

Dari hasil analisis statistik sarana/prasarana kegiatan pada masing masing gugus yaitu: pada gugus Jenderal Sodirman 90,0\% kategori sangat efektif, dan 10,0\% efektif, gugus Rubiah sekar 92,9\% kategori sangat efektif, dan 7,1\% efektif, gugus Krida Manggala $89.7 \%$ sangat efektif, dan $10,3 \%$ efektif, serta gugus Syeh Jambukarang 90,7\% sangat efektif, dan 9,3\% efektif. Dari kategori asingmasing gugus di wilayah UPT Dinas Pendidikan Kecamatan Rembang dapat disimpulkan bahwa komponen anggota dalam pengelolaan kegiatan Kelompok Kerja Guru sangat efektif 90,8\%, dan $9,2 \%$ efektif. Hasil tersebut dapat dilihat pada tabel 6 berikut:
Tabel 6

Kategori Komponen Sarana dan prasarana

\begin{tabular}{|ll|r|r|r|r|r|}
\hline & & \multicolumn{4}{|c|}{ Nama gugus } & \multirow{2}{*}{} \\
\cline { 2 - 6 } & $\begin{array}{c}\text { Jendral } \\
\text { soedirma } \\
\mathrm{n}\end{array}$ & $\begin{array}{c}\text { Rubiah } \\
\text { sekar }\end{array}$ & $\begin{array}{c}\text { Krida } \\
\text { manggala }\end{array}$ & $\begin{array}{c}\text { Syeh } \\
\text { Jambu } \\
\text { Karang }\end{array}$ & Total \\
\hline $\begin{array}{l}\text { Kategori } \\
\text { Kompone } \\
\text { n Sarana } \\
\text { dan } \\
\text { prasarana efektif }\end{array}$ & $\begin{array}{l}\text { Count } \\
\text { samithin } \\
\text { nama } \\
\text { gugus }\end{array}$ & 72 & 65 & 70 & 68 & 275 \\
\hline $\begin{array}{l}\text { Count } \\
\text { \% within } \\
\text { nama } \\
\text { gugus }\end{array}$ & $10.0 \%$ & $72.9 \%$ & $89.7 \%$ & $90.7 \%$ & $90.8 \%$ \\
\hline Total & $\begin{array}{l}\text { Count } \\
\% \text { within } \\
\text { nama } \\
\text { gugus }\end{array}$ & $100.0 \%$ & $100.0 \%$ & $10.3 \%$ & $9.3 \%$ & $9.2 \%$ \\
\hline
\end{tabular}

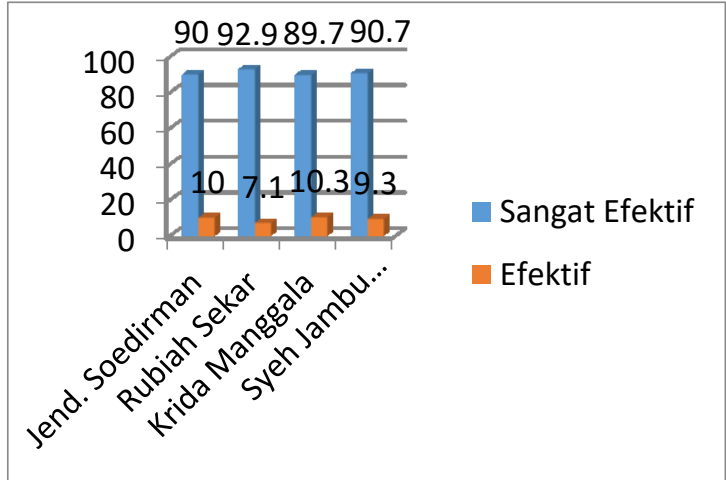

Gambar 5

Efektifitas Komponen Sarana Prasarana

\section{PENUTUP}

Simpulan

Berdasarkan hasil penelitian dapat diambl kesimpulan sebagai berikut:

1. Pengelolaan kegiatan KKG di UPT Dinas Pendidikan Kecamatan Rembang dilihat dari komponen peserta 96,0\%, sangat efektif dan $4,0 \%$ efektif

2. Pegelolaan kegiatan KKG di UPT Dinas Pendidikan Kecamatan Rembang dilihat dari komponen pembina $81,8 \%$, sangat efektif dan $18,2 \%$ efektif

3. Pengelolaan kegiatan KKG di UPT Dinas Pendidikan Kecamatan Rembang dilihat dari komponen materi 80,5\%, sangat efektif dan $19,5 \%$ efektif.

4. Pengelolaan kegiatan KKG di UPT Dinas Pendidikan Kecamatan Rembang dilihat dari komponen kegiatan 96,7\%, sangat efektif dan 3,3\% efektif

5. Pengekokaan kegiatan KKG di UPT Dinas Pendidikan Kecamatan Rembang dilihat dari komponen sarana/prasarana sangat efektif $90,8 \%$, dan $9,2 \%$ efektif 
Saran

1. Peserta gugus hendaknya berperan aktif untuk hadir dan mengikuti kegiatan KKG yang telah terjadwal

2. Standar pengembangan KKG harus dimiliki oleh setiap gugus yang mencakup organisasi, program, pengelolaan, sarana dan prasarana, sumber daya manusia, pembiayaan, dan penjaminan mutu

3. Tempat pelaksanaan kegiatan KKG hendaknya bergilir di sekolah peserta gugus, hal ini dimaksudkan agar guru dapat mendapat pengalaman baru dari sisi lain.

\section{DAFTAR PUSTAKA}

Alba, G.D \& Sandberg, J. (2006). Unveiling professional development: a critical review of stage models. Review of educational research (RER). Jurnal America. DC A Quarterly Publication of The America Educatioal Research Association, Fall 2006, Vol. 76, no 3, pp.384.

Arikunto, Suharsimi. (2004). Manajemen Penelitian, cetakan ke-4. Yogyakarta: Rineka Cipta.

Danim, Sudarwan. (2002). Inovasi Pendidikan. Bandung: Pustaka Setia.

Depdikbud. (2009). Peraturan Pemerintah Nomor 14 Tahun 2005 tentang Guru dan Dosen. Jakarta: Depdiknas.

Fernandes, H.JK. (1984). Evaluation of Education Program. Jakarta: National Educational Planning Evaluation and Curriculum Development.

Hadi, Sutrisno. (2004). Metodologi Research 2. Yogyakarta: Andi.

Kaufman, R \& Thomas, S. (1980). Evaluation without Fear. New York: New Viewpoints.

Komarudin. (2000). Ensiklopedia Manajemen Pendidikan. Bandung: Alumni.

Mahrens, W.A \& Lehmann, IJ. (1973). Measurement of Evaluation in
Education an Psychology. New York: Halt, Richart and Wiston. Inc Nawawi, Hadari. (1981). Administrasi Pendidikan. Jakarta: Gunung Agung.

Rinehart, G. (1999). Quality Education, Appliying the Philosophy of Dr. W. Edwards Deming. Milwaukee. Wilconsin: ASQ Quality Press. Oxford Dictionary.

Sallis, E. (2003). Total Quality Management in Education. London: Kogan Page Educational Management Series.

Shon, Christoper K. (2006). Theacher Professionalism. Faculty Publications And Presentations. Paper 46. Diambil tanggal 29 September 2012 dari http://digitalcommoon.liberty.educ fac pubs/46.

Sugiyono. (2009). Metode Penelitian Pendidikan. Bandung: Alfabeta.

Syah, Muhibbin. (2000). Psikologi Pendidikan dengan Pendekatan Baru. Bandung: Remaja Rosdakarya.

Tim Redaksi. (2005). Undang-undang Nomor 14, Tahun 2005. tentang Guru dan Dosen. Bandung: Fokusmedia.

Thoha, Chotib. (2001). Teknik Evaluasi Pendidikan. Jakarta: Grafinda Rosada.

Weiss, C. H. (1972). Evaluation Research Canada: Prentice-Hall,Inc: New Jersey.

Widoyoko, S.E.P. (2009). Evaluasi Program Pembelajaran. Yogyakarta: Pustaka Pelajar.

Wirawan. (2002). Profesi dan Standar Evaluasi. Jakarta: Yayasan Bangun Indonesia \& UHAMKA.

Worthen, B \& Sanders, JR. (1987). Educational Evaluation: Theory and Practice. Worthington Ohio: Charles A Jones Publishinh Company. 